\title{
Comparative Study of Male Female Disparity in Literacy of Purulia and North 24 Parganas District in West Bengal
}

\author{
Chandra Shekhar Sarkar1 $1^{1 *}$, Aritra Chakraborty2 ${ }^{2}$ \\ ${ }^{1}$ Research Scholar, Dept. of Geography, Presidency University, Kolkata, India \\ ${ }^{2}$ Assistant Professor, Dept. of Geography, Presidency University, Kolkata, India \\ *cssarkar36@gmail.com
}

\begin{abstract}
The present article focuses on a comparative study of the male-female disparity in literacy of two districts Purulia and North 24 Parganas in West Bengal, India. The Census data of 2011 has been used in this regard. The literacy rate has been calculated for the population above six-year, and Sopher's Disparity index (1974) has been applied to measure the male-female disparity in literacy. The study examines the block-level male-female disparity in literacy among non-Schedule Caste (none-SC ST), Scheduled Castes (SC), and Scheduled Tribes (ST). The study highlights that North 24 Parganas is far ahead in terms of literacy than Purulia district. However, there is wide variation in block-level male-female disparity in literacy among the three-caste groups in both the districts. In block-level, the Bundwan block of Purulia district and Barasat-I and Deganga block of North 24 Parganas district occupies a remarkable place in terms of the male-female disparity in literacy among each three-caste group. Conversely, Jhalda-II block in Purulia and Hingalganj block of North 24 Parganas is the most backward block in terms of the male-female disparity in literacy among the all-caste groups. Although the Central and the State Government have taken various schemes to enhance literacy rates and eliminated the male-female disparity in education, more suitable steps need to be followed to implement appropriate measures towards education, especially for the women and other marginalised sections of the society.
\end{abstract}

Keywords

Literacy rate; Male-female disparity; Non-Schedule Caste; Block-level

\section{Introduction}

Literacy is a crucial element for the development of a country (Chattoraj \& Chand, 2015). Literacy plays a significant role in increasing human capital, and it removes inequalities from society in almost all respect (Kumar et al. 2016). Literacy is one of the leading indicators of progress in society. The United Nations Educational Scientific and Cultural Organization (UNESCO) defined literacy as "the ability to identify, understand, interpret, create, communicate and compute, using printed and written materials associated with the varying context. Literacy involves a process of learning to enable an individual to achieve his or her goals to develop his or her knowledge and potential and to participate fully in the wider society" (Barman \& Chouhan, 2017). Women in any nation are the mirror of their civilization. They are a valuable part of society. The position of women in society is the index of the standard of social organization. There is no chance for the welfare of the world unless the condition of women is improved
(Biswas, 2017). In India, women face prejudice at every level in society; they are not treated as equal with men, socially, culturally, educationally, economically, or politically, and as a result, they go down far behind men in almost all spheres of life (Kumar et al. 2016). India ranks 132 out of 187 countries on the gender inequality index, which indicates the backwardness of women in our society (Maji \& Sarkar, 2018). Gender disparity in literacy is one of the significant problems in our country. However, female literacy has been rising over the last few decades and as a result, gender disparity in literacy is continuously declining. As per the Census 2011, the malefemale literacy gap of India is approximately 16.68 percent; though, it was 24.84 and 21.59 percent in the Census year 1991 and 2001 (Majhi \& Sarkar, 2019). Thus, the study of literacy level, gender gap, spatial distribution, trends and patterns are being taken as one of the catalytic parts for a population geographer. The investigation of geographical dissimilarity of the male-female disparity in literacy helps to 
recognize the areas with the deficit, which can developmental measures for those regions

(Mundhe et al. 2017).

The significant research work on the male-female disparity in literacy has been carried out by various scholars like Ghanshyam Prasad Jhariya1 and Dr. C.K. Jain (Jhariya \& Jain, 2014), Dr. Kuntal Kanti Chattoraj and Susanta Chand (Chattoraj \& Chand, 2015), A. A. Mulimani and L. M. Pujar (Mulimani \& Pujar, 2015), Laura D. Smith (Smith, 2015), Roy and Anushri Mondal (Roy \& Mondal, 2015), Narender Kumar, Naresh Kumar and Ritu Rani (Kumar et al. 2016), Bikash Barman and Dr. Pradip Chouhan (Barman \& Chohan, 2017), N. K. Manjunatha and Dr. S. M. Hurakadli (Manjunath \& Hurakadi, 2017), Shyamal Kumar Daripa (Daripa, 2017), Nitin N. Mundhe, Dhondiram B. Pawar and Priyanka D. Rokade (Mundhe et al. 2017), Krishnendu Maji and Dr. Sumana Sarkar (Maji \& Sarkar, 2018), Mahafujur Rahaman and Hasibur Rahaman (Rahaman \& Rahaman, 2018), Somnath Mandal (Mondal, 2018), Ashis Kr. Mukherjee and Moumi Laha (Mukherjee \& Laha, 2019), Debasish Najmus Sakib and Dr. Asheesh Srivastava (Sakib \& Srivastava, 2019), and Dr. A. N. Patil and Dr. S. A. Suryawanshi (Pati \& Suryawanshi, 2019).

Few research works have been done on women's education in Purulia and North 24 Parganas district. Still, block-wise caste-based comparative research work on the male-female disparity in education has been not done. Therefore, the present research work tries to through light on a comparative study of the male-female disparity in literacy in Purulia and North 24 Parganas district of West Bengal.

\section{Objectives}

Objectives of the study are as follows:

1. To examine the district wise spatial variation in literacy rate of West Bengal.

2. To compare the block-wise male-female disparity in literacy among non-Scheduled Caste (non-SC ST), Scheduled Caste (SC), Scheduled help the policymakers to take proper Tribe (ST) in Purulia and North 24 Parganas district of West Bengal.

\section{Study Area}

The study area consists of North 24 Parganas and Purulia district of West Bengal. North 24 Parganas is located in the southeastern part of West Bengal, the latitudinal extension is from $22^{\circ} 11^{\prime} 6^{\prime \prime}, \mathrm{N}$ to $23^{\circ} 15^{\prime} 2^{\prime}, \mathrm{N}$ and longitudinal extension are from $88^{\circ} 20^{\prime} \mathrm{E}$ to $89^{\circ} 5^{\prime} \mathrm{E}$. and the total area is 4,094 square kilometres as per the 2011 census. Purulia district is located in the western part of West Bengal, the latitudinal and longitudinal extension are from $22^{\circ} 42^{\prime} 35^{\prime \prime} \mathrm{N}$ to $23^{\circ} 42^{\prime} 00^{\prime \prime} \mathrm{N}$ and longitudinal extent is from $85^{\circ} 49^{\prime} 25^{\prime \prime}$ E to $86^{\circ} 54^{\prime} 37^{\prime \prime}$ E respectively and the total area is 6,259 square kilometres as per the 2011 census.

\section{Database and Methodology}

The present research work is based on secondary data obtained from the Census of India website (https://censusindia.gov.in/). The literacy rate has been calculated for the population above six years. The male-female disparity in literacy is measured by using the Sopher's Disparity Index (1974) method. Moreover, simple mathematical techniques are used to calculate the various literacy rate and choropleth maps are prepared by using ArcMap-10.3 to shows the spatial distribution pattern of literacy. The formulas for different calculation are as follows:

1. Literacy rate $=\{($ Total literate population $\div$ Total population above 6 years age $)\} \times 100$

\section{Non-SC ST literacy rate $=$}

[\{Total literate population - (SC literate population $+\mathrm{ST}$ literate population $)\} \div\{$ Total population above 6 years age - (SC population above $6+$ ST population above 6 ) $\}] \times 100$

\footnotetext{
3. Disparity Index $=\log \frac{\text { Male literacy rate }}{\text { Female literacy rate }}+$ $\log \frac{100-\text { Female literacy rate }}{100-\text { Male literacy rate }}$
} 


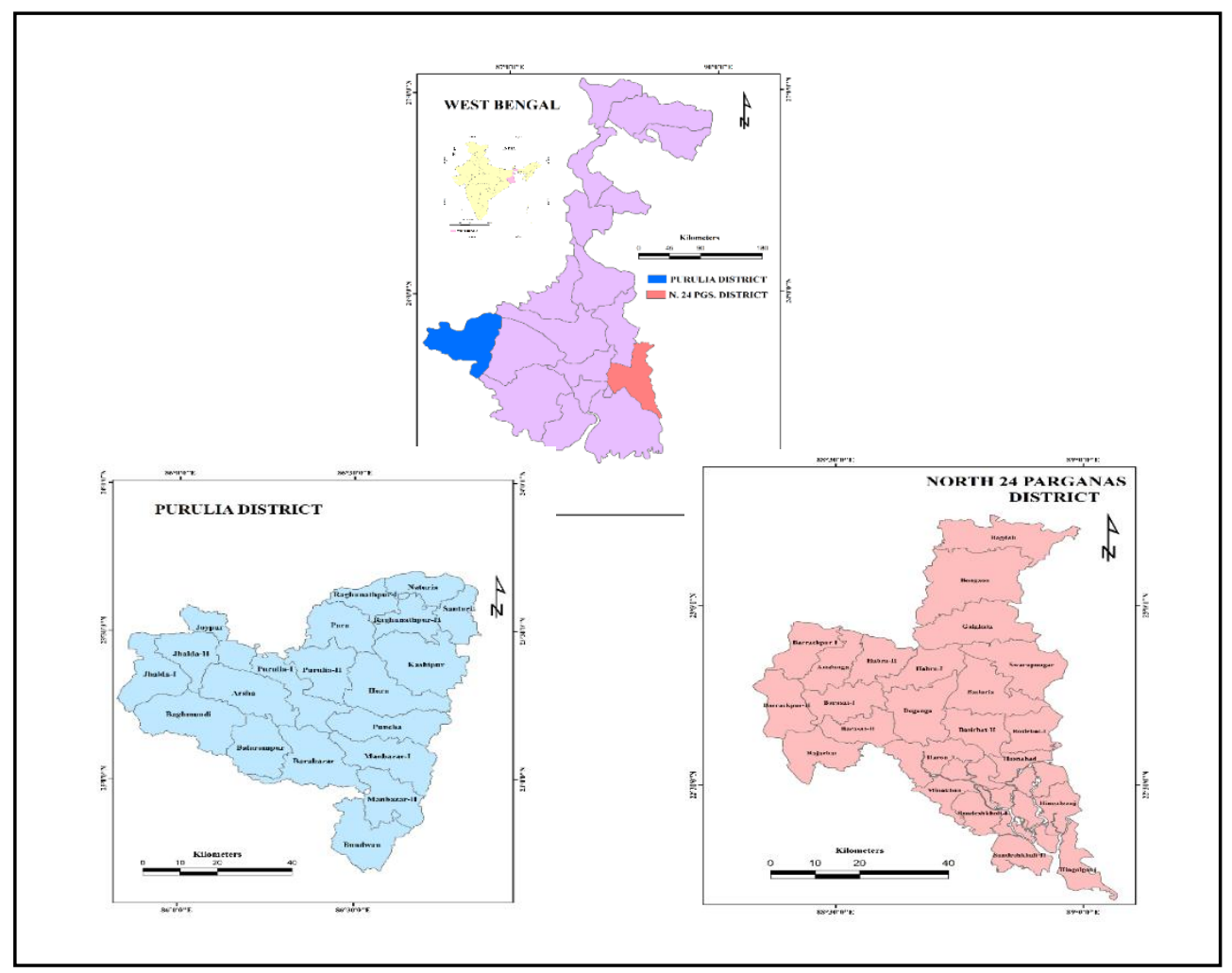

Figure 1. Location map of the study area

\section{Results and Discussions}

\section{Spatial distribution of literacy in West Bengal, 2011}

As per the Census 2011, the literacy rate of West Bengal is 77.1 percent. Although the district wise literacy rate is not uniformly distributed. Table 1 and Figure 2 represents the district wise total, male, female literacy, and male-female literacy difference of West Bengal in 2011. The highest literacy rate is identified in Purba Medinipur (87\%), followed by Kolkata $(86.3 \%)$, North 24 Parganas (84.1\%), Howrah (83.3\%) and Hooghly $(81.8 \%)$ respectively. The lowest literacy rate is found in Dakshin Dinajpur $(59.1 \%)$ and the literacy rate is also very poor in Maldah $(61.7 \%)$, Purulia district $(64.5 \%)$ and Murshidabad (66.6\%). Rest of the eleven districts namely Bankura (70.3\%), Birbhum (70.7\%), Burdwan (76.2\%), Cooch Behar (74.8\%), Dakshin Dinajpur (72.8\%), Darjeeling (79.6\%), Nadia (75\%), Paschim Medinipur (78\%) and South 24 Parganas district $(77.5 \%)$ have moderate literacy rate.

In the case of the male literacy rate, it is also seen that the highest in Purba Medinipur (92.3\%) and lowest in Dakshin Dinajpur (Table-1). The average male literacy rate of West Bengal is 81.7 percent. It is clearly shown that where the total literacy rate is higher, the male literacy rate is also higher. The nine districts namely Purba Medinipur (92.3\%), Kolkata (88.3\%), North 24 Parganas (87.6\%), Hooghly (87\%), Howrah (87\%), Darjeeling (85.6\%), Paschim Medinipur (85.3\%), South 24 Parganas $(83.3 \%)$ and Burdwan district $(82.4 \%)$ have high literacy rate than the State level (81.7\%). On the contrary, the remains ten districts namely Bankura (80\%), Cooch Behar (80.7\%), Jalpaiguri (79.9\%), Birbhum (76.9\%), Nadia (78.8\%), Dakshin Dinajpur (78.4\%), Maldah (66.2\%), Murshidabad (69.9\%) and Uttar Dinajpur district $(65.5 \%)$ have low male literacy rate than the state average.

As per the female literacy rate is concerned, it is noticed that the female literacy rate is slightly unequally distributed compared to district wise total and male literacy rate. The average female literacy rate of West Bengal is 70.5 percent. The female literacy rate is highest in Kolkata $(84.1 \%)$ and lowest in Purulia district (50.5\%). Out of 19 districts, nine districts have their female literacy 
rate above 70 percent. These districts are Darjeeling, Hooghly, Howrah, Kolkata. Nadia, North 24 Parganas, Paschim Medinipur, Purba Medinipur, and South 24 Parganas. Below 65 percent of female literacy is found in five districts namely Burdwan, Cooch Behar, Dakshin Dinajpur and Jalpaiguri and the rest of districts (Uttar Dinajpur, Bankura and Birbhum) female literacy rate is between 65 to 70 percent.

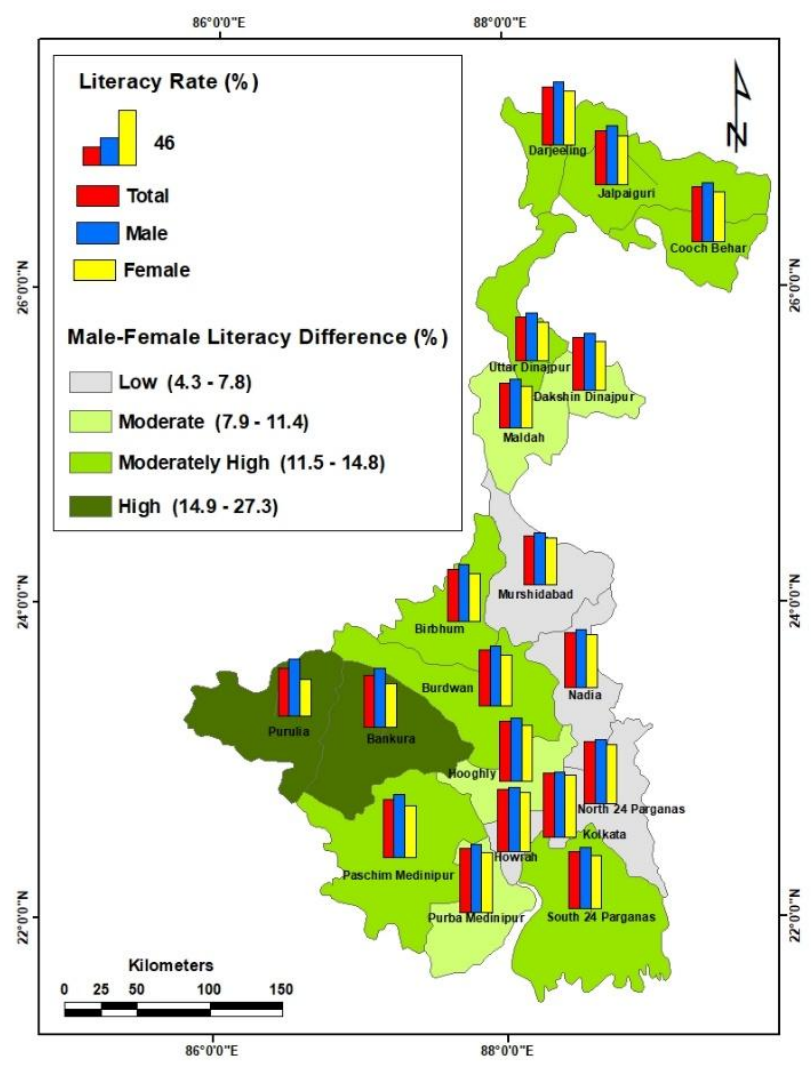

Figure 2. District wise total, male, female literacy rate and male-female literacy difference in West Bengal, 2011

Table 1. District wise literacy rate of West Bengal in 2011

\begin{tabular}{|c|c|c|c|c|c|}
\hline \multirow{2}{*}{$\begin{array}{l}\text { S1. } \\
\text { no. }\end{array}$} & \multirow{2}{*}{ Block name } & \multicolumn{3}{|c|}{ Literacy rate $(\%)$} & \multirow{2}{*}{$\begin{array}{c}\text { Male-female literacy } \\
\text { difference }\end{array}$} \\
\hline & & Total & Male & Female & \\
\hline 1 & Bankura & 70.3 & 80.0 & 60.1 & 20.0 \\
\hline 2 & Birbhum & 70.7 & 76.9 & 64.1 & 12.8 \\
\hline 3 & Burdwan & 76.2 & 82.4 & 69.6 & 12.8 \\
\hline 4 & Cooch Bihar & 74.8 & 80.7 & 68.5 & 12.2 \\
\hline 5 & Dakshin Dinajpur & 72.8 & 78.4 & 67.0 & 11.4 \\
\hline 6 & Darjeeling & 79.6 & 85.6 & 73.3 & 12.3 \\
\hline 7 & Hooghly & 81.8 & 87.0 & 76.4 & 10.7 \\
\hline 8 & Howrah & 83.3 & 87.0 & 79.4 & 7.5 \\
\hline 9 & Jalpaiguri & 73.3 & 79.9 & 66.2 & 13.7 \\
\hline 10 & Kolkata & 86.3 & 88.3 & 84.1 & 4.3 \\
\hline 11 & Maldah & 61.7 & 66.2 & 57.0 & 9.3 \\
\hline 12 & Murshidabad & 66.6 & 69.9 & 63.1 & 6.9 \\
\hline
\end{tabular}




\begin{tabular}{|c|l|l|l|l|l|}
13 & Nadia & 75.0 & 78.8 & 71.0 & 7.8 \\
\hline 14 & North 24 Parganas & 84.1 & 87.6 & 80.3 & 7.3 \\
\hline 15 & $\begin{array}{l}\text { Paschim } \\
\text { Medinipur }\end{array}$ & 78.0 & 85.3 & 70.5 & 14.8 \\
\hline 16 & Purba Medinipur & 87.0 & 92.3 & 81.4 & 11.0 \\
\hline 17 & Purulia & 64.5 & 77.9 & 50.5 & 27.3 \\
\hline 18 & South 24 Parganas & 77.5 & 83.3 & 71.4 & 11.9 \\
\hline 19 & Uttar Dinajpur & 59.1 & 65.5 & 52.2 & 13.3 \\
\hline \multicolumn{4}{|l|}{ West Bengal Source: Author's own calculation using the Census data, 2011 } \\
\hline \multicolumn{5}{|l}{} \\
\hline
\end{tabular}

Table 1 also reveals the difference in district wise male-female literacy. It is found that the maximum gender literacy gap is in Purulia district $(27.3 \%)$ and minimum in Kolkata district (4.3\%). male-female literacy difference is divided into four categories (Figure 2). It is clear from the Figure 2 that low male-female literacy difference (4.3-7.8\%) is found in Kolkata, Howrah, North 24 Parganas, Nadia and Murshidabad, whereas the high literacy gap in Purulia and Bankura district. The moderately high gender literacy gap is found in Darjeeling, Jalpaiguri, Cooch Behar, Uttar Dinajpur, Burdwan, Birbhum, Paschim Medinipur and South 24 Pargana district and rest of the four districts namely Purba Medinipur, Hooghly, Maldah and Dakshin Dinajpur are under moderate male-female literacy difference zone.

2. Comparative analysis of caste wise malefemale disparity in literacy of North 24 Parganas and Purulia district with the State average, 2011

The male-female disparity in literacy means gender inequality in education. The male-female disparity in literacy is calculated based on
Sopher's Disparity Index formula. It measures the degree of gender disparity in literacy. Where the male-female disparity in literacy index is high, gender inequality will be high. On the other hand, if the index value is low, it illustrates the opposite condition. Figure 2 and Table 2 show the castewise male-female disparity in the literacy of West Bengal, North 24 Parganas, and Purulia district in 2011. In the case of the non-SC ST male-female disparity, it is found that male-female disparity in literacy of North 24 Parganas (0.138) is slightly higher than the state average (0.135). Still, it is very high in Purulia district (0.266) compare to the State level and North 24 Parganas district. Besides, SC male-female disparity in the literacy of North 24 Parganas (0.161) is lower than the state average (0.170). Moreover, it is very high in Purulia district (0.283). The same reflection is also observed in ST male-female disparity in literacy, where the male-female disparity in the literacy of North 24 Parganas (0.172) is less than the state average (0.209) and conversely it is much higher in Purulia district $(0.287)$. It is indicated that Purulia district is far behind than North 24 Parganas in terms of caste-wise education.

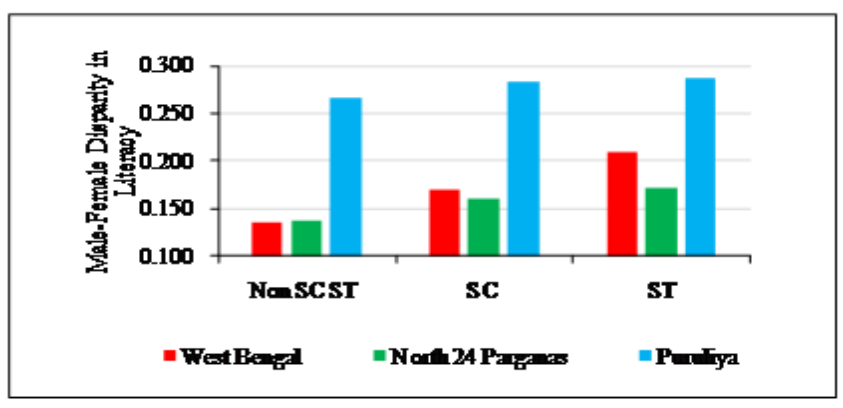

Figure 3. Male-female disparity in literacy in West Bengal and North 24 Parganas and Purulia district, 2011 
Table 2. Non-SC ST, SC, and ST literacy rate of WB, N. 24 Pgs. and Purulia district, 2011

\begin{tabular}{|c|c|c|c|c|c|c|c|c|c|}
\hline \multirow{3}{*}{$\begin{array}{c}\text { District/State } \\
\text { name }\end{array}$} & \multicolumn{9}{|c|}{ Literacy rate $(\%)$} \\
\hline & \multicolumn{2}{|c|}{ Non-SC ST } & \multirow{2}{*}{$\begin{array}{c}\text { Male-female } \\
\text { disparity index }\end{array}$} & \multicolumn{2}{|c|}{$\mathrm{SC}$} & \multirow{2}{*}{$\begin{array}{c}\text { Male-female } \\
\text { disparity index }\end{array}$} & \multicolumn{2}{|c|}{ ST } & \multirow{2}{*}{$\begin{array}{c}\text { Male-female } \\
\text { disparity index }\end{array}$} \\
\hline & Male & Female & & Male & Female & & Male & Female & \\
\hline West Bengal & 84.2 & 75.5 & 0.135 & 77.2 & 61.2 & 0.170 & 68.2 & 47.7 & 0.209 \\
\hline $\begin{array}{l}\text { North } 24 \\
\text { Parganas }\end{array}$ & 88.8 & 83.0 & 0.138 & 85.4 & 73.7 & 0.161 & 72.9 & 56.4 & 0.172 \\
\hline Purulia & 83.2 & 56.5 & 0.266 & 69.8 & 41.6 & 0.283 & 67.8 & 39.8 & 0.287 \\
\hline & & & ource: Author's & n calc & ion usi & he Census data & 11 & & \\
\hline
\end{tabular}

Table 3. Block-wise non-SC ST literacy rate in Purulia and North 24 Parganas district, 2011

\begin{tabular}{|c|c|c|c|c|c|c|c|c|c|}
\hline \multicolumn{10}{|c|}{ Non-SC ST literacy rate $(\%)$} \\
\hline \multicolumn{5}{|c|}{ Purulia district } & \multicolumn{5}{|c|}{ North 24 Parganas district } \\
\hline $\begin{array}{l}\text { Sl. } \\
\text { no. }\end{array}$ & Block name & Male & Female & $\begin{array}{l}\text { Male-female } \\
\text { disparity index }\end{array}$ & $\begin{array}{l}\text { Sl. } \\
\text { no }\end{array}$ & Block name & Male & Female & $\begin{array}{l}\text { Male-female } \\
\text { disparity index }\end{array}$ \\
\hline 1 & Arsha & 75.2 & 41.6 & 0.328 & 1 & Amdanga & 84.7 & 79.1 & 0.116 \\
\hline 2 & Bagmundi & 79.8 & 47.4 & 0.311 & 2 & Baduria & 81.9 & 76.0 & 0.109 \\
\hline 3 & Balarampur & 82.0 & 54.2 & 0.272 & 3 & Bagdah & 81.9 & 74.1 & 0.121 \\
\hline 4 & Barabazar & 81.3 & 52.2 & 0.282 & 4 & Barasat - I & 84.8 & 79.7 & 0.112 \\
\hline 5 & Bundwan & 82.1 & 56.2 & 0.257 & 5 & Barasat - II & 82.1 & 75.2 & 0.116 \\
\hline 6 & Hura & 87.9 & 62.8 & 0.276 & 6 & Barrackpur - I & 91.3 & 84.9 & 0.166 \\
\hline 7 & Jaipur & 74.8 & 45.2 & 0.288 & 7 & Barrackpur - II & 89.0 & 82.5 & 0.146 \\
\hline 8 & Jhalda - I & 83.6 & 55.0 & 0.283 & 8 & Basirhat - I & 75.8 & 69.3 & 0.100 \\
\hline 9 & Jhalda - II & 77.1 & 38.6 & 0.379 & 9 & Basirhat - II & 82.0 & 76.1 & 0.109 \\
\hline 10 & Kashipur & 90.3 & 70.0 & 0.263 & 10 & Bongaon & 84.9 & 78.0 & 0.126 \\
\hline 11 & Manbazar - I & 84.0 & 57.1 & 0.270 & 11 & Deganga & 83.7 & 78.2 & 0.112 \\
\hline 12 & Manbazar - II & 80.1 & 52.6 & 0.267 & 12 & Gaighata & 89.5 & 81.8 & 0.159 \\
\hline 13 & Neturia & 85.2 & 61.4 & 0.249 & 13 & Habra - I & 88.3 & 82.2 & 0.138 \\
\hline 14 & Para & 84.9 & 57.3 & 0.279 & 14 & Habra - II & 85.6 & 79.5 & 0.123 \\
\hline 15 & Puncha & 87.2 & 61.6 & 0.275 & 15 & Haroa & 78.8 & 71.0 & 0.115 \\
\hline 16 & Purulia - I & 81.4 & 53.9 & 0.269 & 16 & Hasnabad & 75.4 & 67.0 & 0.113 \\
\hline 17 & Purulia - II & 81.5 & 54.7 & 0.263 & 17 & Hingalganj & 80.8 & 66.4 & 0.165 \\
\hline 18 & Raghunathpur - I & 89.1 & 68.6 & 0.251 & 18 & Minakhan & 77.1 & 67.8 & 0.121 \\
\hline 19 & Raghunathpur - II & 86.6 & 59.8 & 0.281 & 19 & Rajarhat & 87.3 & 80.8 & 0.135 \\
\hline 20 & Santuri & 85.8 & 62.5 & 0.249 & 20 & Sandeshkhali - I & 78.1 & 67.1 & 0.135 \\
\hline \multirow{2}{*}{\multicolumn{5}{|c|}{$\begin{array}{l}\text { Source: Author's own calculation using the Census data, } \\
2011\end{array}$}} & 21 & Sandeshkhali - II & 78.8 & 65.9 & 0.150 \\
\hline & & & & & 22 & Swarupnagar & 80.9 & 73.6 & 0.115 \\
\hline
\end{tabular}

Table 4. Block-wise SC literacy rate in Purulia and North 24 Parganas district, 2011

\begin{tabular}{|c|c|c|c|c|c|c|c|c|c|}
\hline \multicolumn{10}{|c|}{ SC literacy rate $(\%)$} \\
\hline \multicolumn{5}{|c|}{ Purulia district } & \multicolumn{5}{|c|}{ North 24 Parganas district } \\
\hline $\begin{array}{l}\text { Sl. } \\
\text { no. }\end{array}$ & Block name & Male & Female & $\begin{array}{l}\text { Male-female } \\
\text { disparity index }\end{array}$ & $\begin{array}{l}\text { Sl. } \\
\text { no }\end{array}$ & Block name & Male & Female & $\begin{array}{l}\text { Male-female } \\
\text { disparity index }\end{array}$ \\
\hline 1 & Arsha & 62.9 & 35.4 & 0.298 & 1 & Amdanga & 82.3 & 69.6 & 0.157 \\
\hline 2 & Bagmundi & 49.0 & 24.5 & 0.337 & 2 & Baduria & 83.5 & 72.5 & 0.149 \\
\hline 3 & Balarampur & 69.9 & 40.6 & 0.295 & 3 & Bagdah & 80.9 & 69.5 & 0.143 \\
\hline 4 & Barabazar & 68.5 & 39.6 & 0.295 & 4 & Barasat - I & 83.3 & 72.8 & 0.145 \\
\hline
\end{tabular}




\begin{tabular}{|c|c|c|c|c|c|c|c|c|c|}
\hline 5 & Bundwan & 80.6 & 57.5 & 0.231 & 5 & Barasat - II & 78.8 & 63.2 & 0.170 \\
\hline 6 & Hura & 74.6 & 45.8 & 0.280 & 6 & Barrackpur - I & 86.2 & 74.0 & 0.169 \\
\hline 7 & Jaipur & 64.9 & 36.1 & 0.305 & 7 & Barrackpur - II & 87.0 & 75.8 & 0.166 \\
\hline 8 & Jhalda - I & 66.6 & 38.0 & 0.298 & 8 & Basirhat - I & 76.7 & 61.6 & 0.163 \\
\hline 9 & Jhalda - II & 54.7 & 26.2 & 0.361 & 9 & Basirhat - II & 83.9 & 69.4 & 0.174 \\
\hline 10 & Kashipur & 77.4 & 50.0 & 0.265 & 10 & Bongaon & 84.6 & 73.1 & 0.156 \\
\hline 11 & Manbazar - I & 68.3 & 37.5 & 0.317 & 11 & Deganga & 78.0 & 64.9 & 0.150 \\
\hline 12 & Manbazar - II & 75.0 & 47.5 & 0.267 & 12 & Gaighata & 84.8 & 74.0 & 0.153 \\
\hline 13 & Neturia & 72.8 & 46.8 & 0.255 & 13 & Habra - I & 86.4 & 75.0 & 0.164 \\
\hline 14 & Para & 70.3 & 39.4 & 0.311 & 14 & Habra - II & 83.1 & 70.3 & 0.160 \\
\hline 15 & Puncha & 68.6 & 43.3 & 0.256 & 15 & Haroa & 79.3 & 64.0 & 0.169 \\
\hline 16 & Purulia - I & 69.9 & 39.6 & 0.306 & 16 & Hasnabad & 80.5 & 67.0 & 0.158 \\
\hline 17 & Purulia - II & 66.9 & 38.3 & 0.296 & 17 & Hingalganj & 86.6 & 71.9 & 0.188 \\
\hline 18 & Raghunathpur - I & 66.9 & 39.7 & 0.281 & 18 & Minakhan & 80.7 & 65.0 & 0.173 \\
\hline 19 & Raghunathpur - II & 73.5 & 43.8 & 0.291 & 19 & Rajarhat & 87.1 & 75.2 & 0.172 \\
\hline 20 & Santuri & 70.1 & 45.8 & 0.243 & 20 & Sandeshkhali-I & 84.3 & 68.8 & 0.183 \\
\hline \multirow{2}{*}{\multicolumn{5}{|c|}{$\begin{array}{l}\text { Source: Author's own calculation using the Census data, } \\
2011\end{array}$}} & 21 & Sandeshkhali-II & 85.1 & 68.4 & 0.195 \\
\hline & & & & & 22 & Swarupnagar & 83.8 & 72.2 & 0.154 \\
\hline
\end{tabular}

Table 5. Block-wise ST literacy rate in Purulia and North 24 Parganas district, 2011

\begin{tabular}{|c|c|c|c|c|c|c|c|c|c|}
\hline \multicolumn{10}{|c|}{ ST literacy rate $(\%)$} \\
\hline \multicolumn{5}{|c|}{ Purulia district } & \multicolumn{5}{|c|}{ North 24 Parganas district } \\
\hline $\begin{array}{l}\text { Sl. } \\
\text { no. }\end{array}$ & Block name & Male & Female & $\begin{array}{c}\text { Male-female } \\
\text { disparity } \\
\text { index }\end{array}$ & $\begin{array}{c}\text { S1. } \\
\text { no } \\
\text {. }\end{array}$ & Block name & Male & Female & $\begin{array}{l}\text { Male-female } \\
\text { disparity index }\end{array}$ \\
\hline 1 & Arsha & 59.2 & 31.8 & 0.315 & 1 & Amdanga & 73.8 & 59.2 & 0.158 \\
\hline 2 & Bagmundi & 61.2 & 32.8 & 0.318 & 2 & Baduria & 72.9 & 57.7 & 0.161 \\
\hline 3 & Balarampur & 61.5 & 32.9 & 0.319 & 3 & Bagdah & 61.5 & 43.2 & 0.200 \\
\hline 4 & Barabazar & 68.1 & 37.1 & 0.320 & 4 & Barasat - I & 70.9 & 61.2 & 0.118 \\
\hline 5 & Bundwan & 67.5 & 40.3 & 0.278 & 5 & Barasat - II & 62.5 & 47.7 & 0.163 \\
\hline 6 & Hura & 74.3 & 46.4 & 0.272 & 6 & Barrackpur - I & 86.2 & 66.3 & 0.225 \\
\hline 7 & Jaipur & 61.2 & 34.0 & 0.302 & 7 & Barrackpur - II & 81.5 & 68.3 & 0.158 \\
\hline 8 & Jhalda - I & 71.2 & 43.2 & 0.278 & 8 & Basirhat - I & 72.6 & 57.0 & 0.165 \\
\hline 9 & Jhalda - II & 60.0 & 31.1 & 0.332 & 9 & Basirhat - II & 62.8 & 46.0 & 0.182 \\
\hline 10 & Kashipur & 74.5 & 48.1 & 0.257 & 10 & Bongaon & 70.7 & 53.2 & 0.181 \\
\hline 11 & Manbazar - I & 71.7 & 41.7 & 0.299 & 11 & Deganga & 62.6 & 51.1 & 0.134 \\
\hline 12 & Manbazar - II & 69.6 & 39.5 & 0.305 & 12 & Gaighata & 70.7 & 56.5 & 0.153 \\
\hline 13 & Neturia & 65.9 & 38.9 & 0.282 & 13 & Habra - I & 69.0 & 55.2 & 0.150 \\
\hline 14 & Para & 75.6 & 44.9 & 0.298 & 14 & Habra - II & 70.5 & 51.2 & 0.196 \\
\hline 15 & Puncha & 72.9 & 44.9 & 0.275 & 15 & Haroa & 64.6 & 45.5 & 0.202 \\
\hline 16 & Purulia - I & 68.2 & 41.0 & 0.277 & 16 & Hasnabad & 65.3 & 48.8 & 0.176 \\
\hline 17 & Purulia - II & 64.1 & 39.4 & 0.261 & 17 & Hingalganj & 75.0 & 54.3 & 0.207 \\
\hline 18 & Raghunathpur - I & 63.3 & 37.8 & 0.272 & 18 & Minakhan & 66.4 & 48.6 & 0.186 \\
\hline 19 & Raghunathpur - II & 71.5 & 41.5 & 0.298 & 19 & Rajarhat & 88.1 & 78.4 & 0.163 \\
\hline 20 & Santuri & 68.3 & 41.7 & 0.270 & 20 & Sandeshkhali - I & 70.5 & 52.6 & 0.184 \\
\hline \multirow{2}{*}{\multicolumn{5}{|c|}{$\begin{array}{l}\text { Source: Author's own calculation using the Census data, } \\
2011\end{array}$}} & 21 & Sandeshkhali - II & 67.5 & 46.5 & 0.215 \\
\hline & & & & & 22 & Swarupnagar & 84.5 & 76.0 & 0.136 \\
\hline
\end{tabular}

3. Block-wise non-Schedule Caste (non-SC ST) male-female disparity in literacy of Purulia and North 24 Parganas district, 2011
Figure 4 and 5 reveals the block-wise nonSchedule Caste (non-SC ST) male-female disparity in the literacy of Purulia and North 24 
Parganas district in 2011. The block-wise non-SC ST male-female disparity of Purulia district is comparatively higher than North 24 Pargana. In Purulia, Jhalda II rank $1^{\text {st }}$ with male-female disparity index value 0.379 , followed by Arsha (0.349) and Baghmundi block (0.311) respectively. Whereas Neturia and Santuri block both are on the bottom with the same index value of 0.249 (Table 3). Five blocks with low non-SC ST male-female disparity index value (0.3290.375) are Bundwan, Raghunathpur I, Neturia and Santuri. While thirteen blocks in the middle eastern part of the district namely Jhalda I, Joypur, Purulia I, Purulia II, Balarampur, Barabazar, Manbazar I, Manbazar II, Puncha, Hura, Para, Kashipur and Raghunathpur II have moderate non-SC ST male-female disparity index value (0.258-0.288). Two blocks (Baghmundi, Arsha) of the western part are under Moderately high nonSCST male-female disparity in the literacy index value. Besides, only one block (Jhalda II) is under High index value.

In North 24 Parganas, non-SC ST male-female disparity in literacy index value varies from 0.166

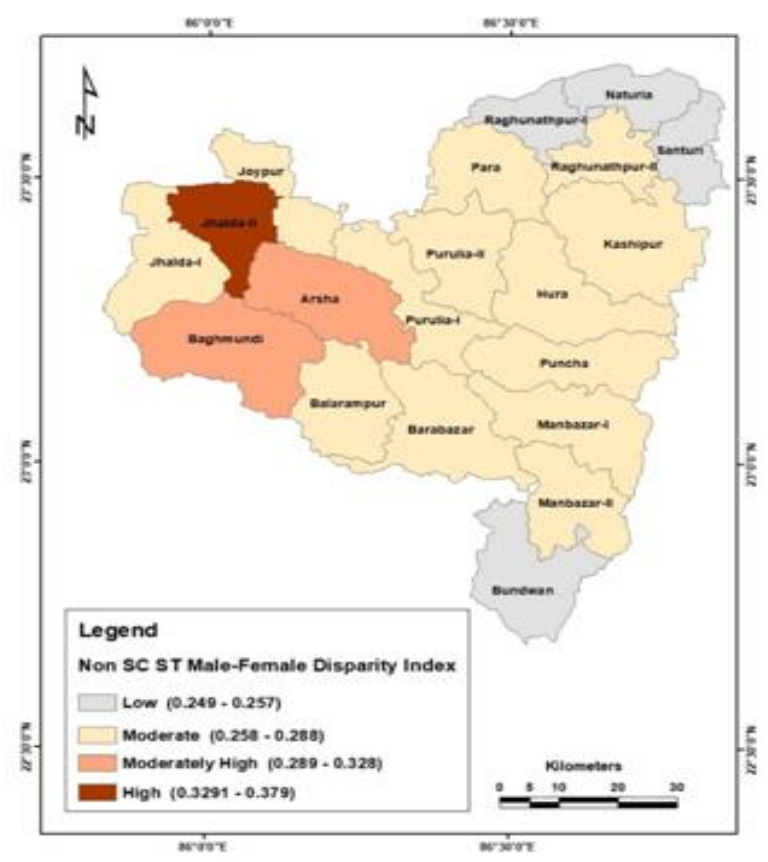

Figure 4. Block-wise non- Schedule Caste (non-SC ST) male-female disparity in literacy in Purulia district, 2011 in Barrackpur I block to 0.100 in Basirhat I (Table 4). Based on the spatial variation of the non-SC ST male-female index value, the district has been divided into four broad categories. It can be easily observed from the Figure 5 that six blocks which are located in the middle and eastern part of the district namely Barasat-I, Deganga, Baduria, Basirhat-I, Basirhat-II and Hasnabad have emerged as a region of considerably low non-SC ST male-female disparity in literacy index (0.1500.167). Eight blocks, namely Bagdah, Bongaon, Amdanga, Habra II, Swarupnagar, Barasat II, Haroa, Minakhan fall under moderate non-SC ST male-female disparity index value region. On the other hand, four-block (Barrackpur-II, Rajarhat, Habra-I, Sandeshkhali-I and Sandeshkhali-II) falls into the moderately high zone, while three blocks (Hingalganj, Gaighata and Barrackpur I) under high categories of non-SC ST male-female disparity in literacy index (0.150-0.167).

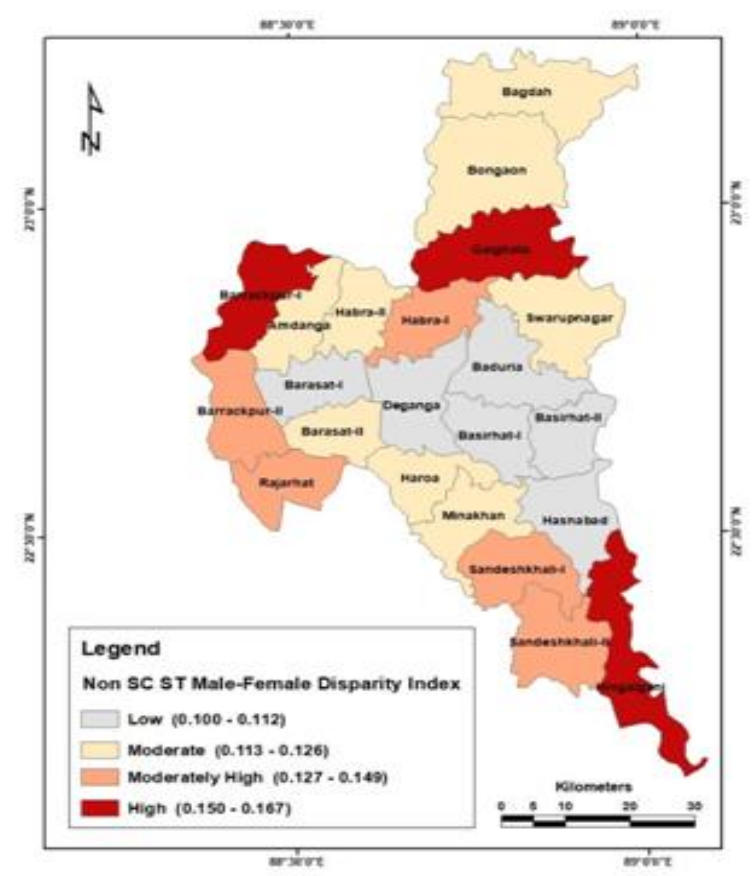

Figure 5. Block-wise non-Schedule Caste (non-SC ST) male-female disparity in literacy in North 24 Parganas district, 2011 
4. Block-wise Schedule Caste (SC) male-female disparity in literacy of Purulia and North 24 Parganas district, 2011

Figure 6 and 7 demonstrate the block-wise spatial distribution of Schedule Caste (SC) male-female disparity in the literacy of Purulia and North 24 Parganas district in 2011. In Purulia district, among twenty blocks, the SC male-female disparity in literacy is highest in the Jhalda II block (0.361, Table-4) and lowest in Bundwan block (0.231, Table-4)). SC male-female disparity in literacy is divided into four-zones (Figure-6) such as low (0.231-0.256), Moderate (0.257$0.281)$, moderately high (0.282-0.317) and high (0.318-0.361). Four blocks such as Bundwan. Puncha, Santuri, and Naturiashows the low SC male-female disparity in literacy. Four blocks namely Manbazar-II, Hura, Kashipur, Raghunathpur-I, are under moderate SC malefemale disparity in literacy zone. One the other hand, ten blocks which are mainly located in the middle part, falls into moderately high SC malefemale disparity in the literacy zone. These blocks are Arsha, Purulia-I, Purulia-II, Para, Raghunathpur-II, Balarampur, Barabazar, Manbazar-I and Jhalda-I. While only two blocksBaghmundi (0.337)) and Jhalda-II (0.361) are under high disparity zone. It can clearly visible that the SC gender gap in literacy is lass compare to the western part of the Purulia district.

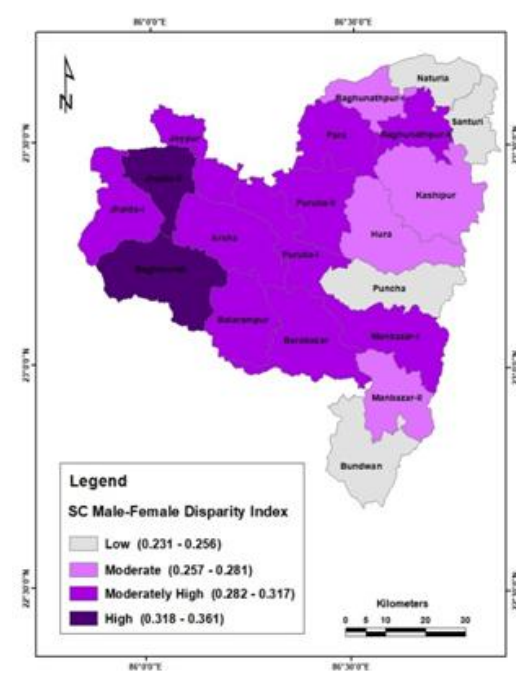

Figure 6. Block-wise Schedule Caste (SC) male-female disparity in literacy in Purulia district, 2011
In North 24 Parganas, the Schedule Caste (SC) male-female disparity in literacy is much better than the Purulia district. Out of 22 blocks of North 24 Parganas district, Sandeshkhali-II (0.195, Table-4) has the highest SC male-female disparity in literacy and lowest in Bagdah (0.1430, Table4). Like Purulia district, the spatial distribution of SC male-female disparity in the literacy of North 24 Pargana is divided into five categories; these are low (0.143-0.150), moderate (0.151-0.1600, moderately high (0.161-0.174) and high (0.1740.195). Three blocks of the middle part of the district like Barasat-I (0.145), Deganga (0.150), and Baduria (0.149) and one northernmost block Bagdah (0.143) are under low disparity categories. Conversely, three-blocks, which are located in the southern part of the district namely Sandeskhhali-I (0.183), Sandeshkhali-II (0.195) and Hingalganj (0.188) fall into high SC male-female disparity in literacy categories. On the other hand, moderately high literacy is found in nine blocks, which are Barrackpur-I (0.169), Barrackpur-II (0.166), Rajarhat (0.172), Barasat-II (0.170), Habra-I (0.164), Haroa (0.169), Basirhat-I (0.163), Basirhat-II (0.0.174) and Minakhan block (0.173). Remains six-block namely Bongaon, Gaighata, Amdanga, Habra-II, Swrupnagar and Hasnabad, are under Moderate SC male-female disparity in literacy categories. Overall, it can be said that block-level SC male-female disparity in literacy condition is good.

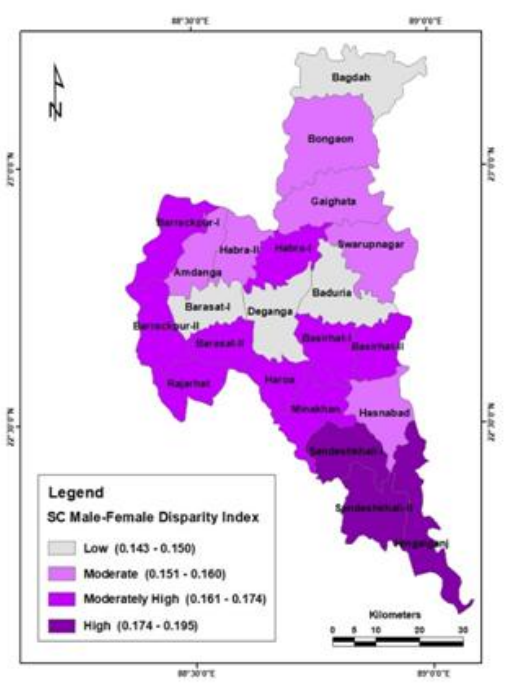

Figure 7. Block-wise Schedule Caste (SC) male-female disparity in literacy in North 24 Parganas district, 2011 
5. Block-wise Schedule Tribe (ST) male-female disparity in literacy of Purulia and North 24 Parganas district, 2011

Likewise, the block-level non-SC ST and SC male-female disparity in literacy, there is also a wide difference in terms of block-level Schedule Tribe (ST) male-female disparity in literacy between Purulia and North 24 Parganas district. Figure- 8 and 9 represent the block-wise ST malefemale disparity in the literacy of Purulia and North 24 Parganas district in 2011. In Purulia district, the maximum ST male-female disparity in literacy is found in Jhalda-II (0.332, Table-5) and minimum in Khasipur (0.257, Table-5). From Figure-8, it can be easily identified that two blocks of the Purulia district like Kashipur (0.257) and Purulia-II block (0.261) have the low SC male-female disparity in literacy (0.257-0.261). Out of 20 blocks, eight blocks show the moderate SC male-female disparity in literacy. These blocks are Purulia-I (0.277), Hura (0.0.272), Puncha (0.275), Bundwan (0.278), Raghunathpur-I (0.272), Natori (0.282), Santuri $(0.2720$ and Jhalda (0.278). While five blocks like Para (0.298), Raghunathpur-II (0.298), Joypur (0.302), Manbazar-I (0.299), and Manbazar-II (0.305) are under moderately high SC male-female disparity in literacy area. Western (except Jhalda-I and Joypur) and south-western blocks of the district have displayed low SC male-female disparity in

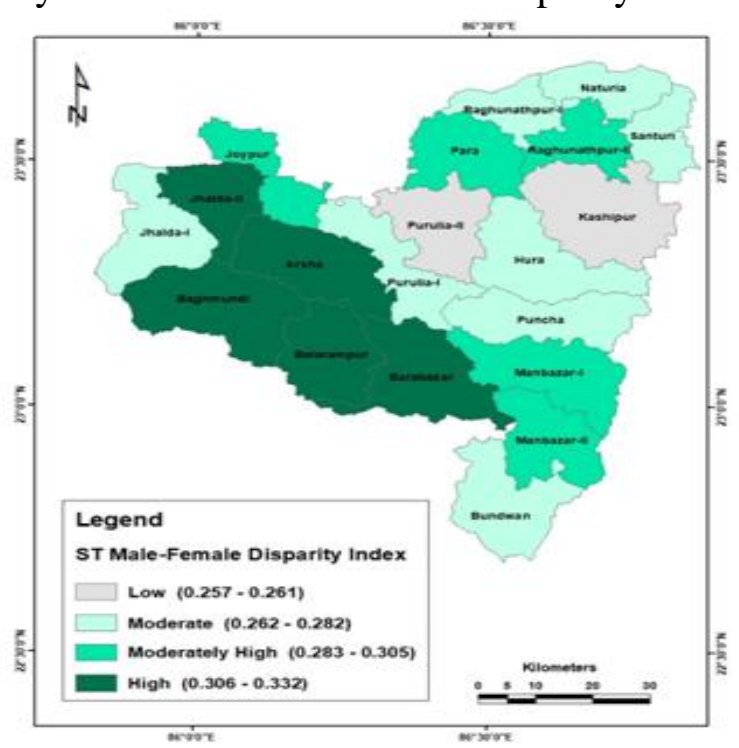

Figure 8. Block-Wise Schedule Tribe (ST) male-female disparity in literacy in Purulia district, 2011 literacy (0.303-0.332). These blocks are Jhalda-II (0.332), Arsha (0.315), Baghmundi (.0318), Balarampur (0.319) and Barabazar (0.320).

In the case of North 24 Parganas, the block-wise ST male-female disparity in literacy index value is much lower than the Purulia district, which indicated the comparatively better ST male-female educational status in North 24 Parganas. The ST male-female disparity in the literacy of the district varies from 0.225 in Barrackpur-I block to 0.118 in Barasat-I (Table-5). Figure-9 delineates the block-wise ST male-female disparity of the North 24 Parganas district, where the disparity in literacy is divided into five categories. Out of 22 blocks of the district, three blocks namely Barasat-I, Deganga and Swarupnagar, in which ST male-female disparity in literacy index value is low (0.118-0.136). In contrast, ST male-female disparity in literacy is high in five blocks such as Bagdah, Habra-II, Barrackpur-I, Haroa, Sandeskhali-II and Hingalganj. On the other hand, five blocks namely Bongaon, Minakha, BasirhatII, Hasnabad and Sandeshkhali-I, show the moderately high ST gender disparity in literacy. The remains eight blocks of the district such as Gaighata, Amdanga, Habra-I, Baduria, Barrackpur, Rajarhat, Barasat-II, Baduria and Barasat-I fall into moderate ST male-female disparity in literacy.

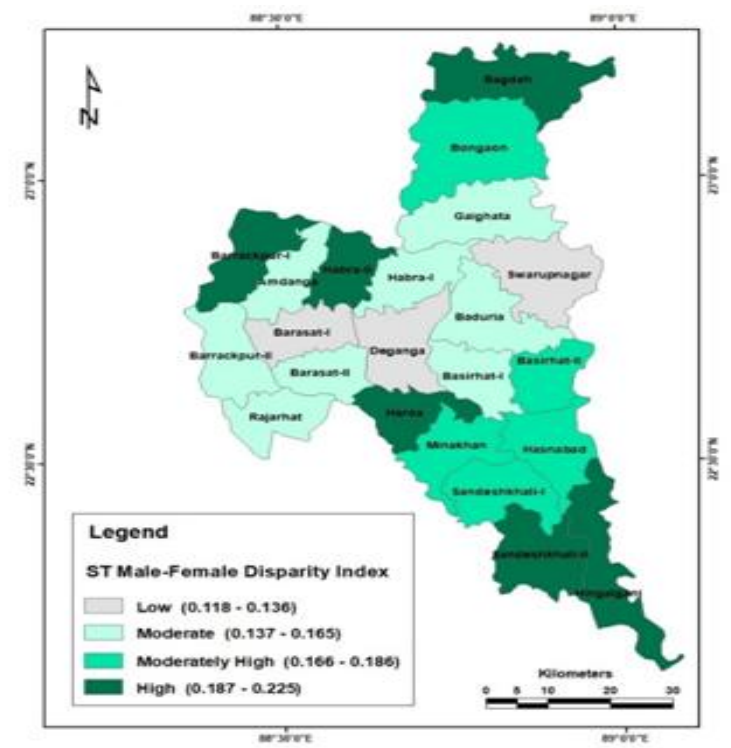

Figure 9. Block-Wise Schedule Tribe (ST) male-female disparity in literacy in North 24 Parganas district, 2011 


\section{Conclusion}

It may be concluded that there is a wide gap in male-female disparity in literacy between Purulia and North 24 Parganas district of West Bengal. It is found that North 24 Parganas is far ahead than Purulia district in terms of male and female literacy among the non- Scheduled caste (non-SC ST), Scheduled Caste (SC), and Scheduled Tribe (ST). However, there is variation in male-female disparity at the block level in both districts. Besides, it is interesting to know that the blocks of North 24 Parganas, which are lagging behind in male-female disparity in literacy index value, are ahead of developed blocks of Purulia district. In Purulia, mainly in three blocks like Jhalda-II, Arsha and Baghmundi, the male-female disparity in literacy is high among non-Scheduled Caste (non-SC ST), Scheduled Caste (SC) and Scheduled Tribe (ST). Whereas, three blocks of North 24 Parganas such as Sandeshkhali-II, Hingalganj and Barrackpur-I have high malefemale disparity in literacy among non-Scheduled caste, Scheduled Caste and Scheduled Tribe. The geographical location may be the main cause of the educational disparities between these two districts. North 24 Parganas belongs to the fertile plains of the Gangetic delta, as well as the district is located near the capital city Kolkata. On the other hand, Purulia district is the westernmost district of West Bengal, which belongs to undulated topography and there is no metropolitan city nearby. It can also be said that Purulia district is socio-economically underdeveloped compared to North 24 Parganas. The Central Government of India and the State Government of West Bengal have started various schemes to uplift the literacy level; but still, the disparity in gender literacy is high. The Central and State Government should focus on the backward districts to eliminate malefemale disparity in literacy and should take adequate measures to increase the literacy rate in the marginalized section of the society.

\section{References}

1. Barman, B., \& Chouhan, P. (2017). Spatiotemporal Variation in Literacy among the Scheduled Caste Population: A Sub- divisional Scenario of Koch Bihar District, West Bengal, India. IOSR Journal of Humanities and Social Science (IOSR-JHSS), 22(7), 01-11.

2. Biswas, S. (2017). Educational Status of Women in West Bengal. JETIR, 4(11), 928940.

3. Chattoraj, K. Kuntal., \& Chand, S. (2015). Literacy Trend of West Bengal and Its Differentials: A District-Level Analysis. IOSR Journal of Humanities and Social Science (IOSR-JHSS). 20(9), 01-19.

4. Dandapat, K. A., \& Manna, S. (2019). A Comparative Study of Education in Tribal and Non-Tribal Women in West Bengal. International Journal of Advanced Research (IJAR), 7(5), 1341-1348.

5. Daripa, K. S. (2017). A comparative study of the Educational status of Tribal in West Bengal: With Special Reference to the District of Purulia. International Journal of Research in Social Sciences, 7(10), 658-670.

6. Jhariya, P. G., \& Jain, K. C. (2014). Pattern and Differential of Literacy in Madhya Pradesh. IOSR Journal of Humanities and Social Science (IOSR-JHSS), 19(9), 77-84.

7. Manjunatha, K. N., \& Hurakadli, M. S. (2017) A Discourse on Gender Disparity: A Study on Taluks of Belagavi District. International Journal of Trend in Scientific Research and Development (IJTSRD), 1(5), 1126-1131.

8. Kumar, N., Kumar, N., and Rani, R. (2016). Gender Disparity in Literacy: Districts Level Evidence from Selected States of India. Educational Quest: An Int. J. of Education and Applied Social Sciences, 7 (3), 243-254.

9. Maji, K., \& Sarkar, S. (2018). Gender Disparity in Literacy Level among Scheduled and Nonscheduled Population: A Case Study of Bankura District, West Bengal (India). International journal of basic and applied research, 8, 537-554.

10. Mandal, S. (2018). Differences in Literacy: An Integrated Block Level Analysis in Western Part of West Bengal. International Journal of Social Science and Economic Research, 3(8), 3941-3956.

11. Mukherjee, K. A., \& Laha, M. (2019). Status of rural literacy in Purulia district, West 
Bengal. International Journal of Applied Research, 5(3), (2019), 32-44.

12. Mukherjee, N. (2015). Gender Inequality Index: A Comparative Study Based on Districts of West Bengal. International Journal of Economic and Business Review, 3(6), 162-165.

13. Mulimani, A. A., \& Pujar, M. L. (2015) Spatial Disparity of Rural-Urban Literacy in Haveri District. International Multidisciplinary Research Journal, 3(6), 110.

14. Mundhe, N. N., Pawar, B. D., \& Rokade, D. P. (2017). Use of Disparity Index for Identifying Rural-Urban Literacy Pattern of Pune District, Maharashtra. IMPACT: International Journal of Research in Humanities, Arts and Literature (IMPACT: IJRHAL), 5(8), 61-70.

15. Patil, A. N., \& Suryawanshi, S. A. (2019). Disparity in the Level of Literacy a SpatioTemporal Case Study of Jalgaon District Maharashtra State (2001-2011). Journal of Emerging Technologies and Innovative Research (JETIR), 6(3), 396-402.

16. Rahaman, M., \& Rahaman, H. (2018). Gender Disparity in Literacy in Maldah District. International Journal of Research in Social Sciences, 8(10), 123-141.

17. Roy, D., \& Mondal, A. (2015). Rural-Urban Disparity of Literacy in Murshidabad District, WB, India. International Research Journal of Social Sciences, 4(7), 19-23.

18. Rukhsana., \& Alam, A. (2014). Literacy Differentials among Scheduled Caste and Non-Schedule Castes in West Bengal, India: A District Wise Study. International Journal of Innovative Research in Science, Engineering and Technology, 3(3), 1070510712.

19. Sopher, D. E. (1974). A Measure of Disparity. The Professional Geographer. 